\title{
THE INFLUENCE OF BREED OF EWE AND OFFSPRING ON LITTER SIZE AFTER EGG TRANSFER IN SHEEP
}

\author{
R. A. S. LAWSON AND L. E. A. ROWSON \\ A.R.C. Unit of Reproductive Physiology and Biochemistry, \\ Animal Research Station, 307 Huntingdon Road, Cambridge
}

(Received 22nd June 1971, accepted 12th Fuly 1971)

\begin{abstract}
Summary. In order to investigate the influences of maternal and embryonic genotype on litter size, fertilized eggs were transferred, at a rate of five per recipient, from Clun Forest ewes to Romney Marsh, Suffolk and Finnish Landrace ewes, and also from Romney Marsh and Finnish Landrace ewes to Romney Marsh ewes. The numbers of natural ovulations (corpora lutea) were counted in recipient ewes at the time of transfer. All ewes which became pregnant were allowed to lamb.

Differences in conception rate and litter size at birth between the three breeds which received Glun Forest eggs were not significant, but, taken together, these differences resulted in the survival of significantly more of the transferred eggs when the recipient ewes were Finnish Landrace $(63 \%)$ than when they were Romney Marsh $(47 \%)$ or Suffolk (43\%). In Romney Marsh ewes, the survival rate of Romney Marsh eggs tended to be poorer (33\%) than that of alien Clun Forest $(47 \%)$ or Finnish Landrace (44\%) eggs but this effect was not significant.

Irrespective of the genotype of the eggs transferred, the mean size of litters from Romney Marsh ewes following transfer of five eggs was significantly greater than the potential litter size of this breed determined by natural ovulation rate.

It was concluded that ovulation rate was the major factor limiting fertility in the Romney Marsh breed. Differences do seem to exist between breeds of sheep in the numbers of offspring which the uterus is able to support, but, in the breeds studied, this control did not appear to limit litter size below levels which are desirable in practice.
\end{abstract}

\section{INTRODUCTION}

The characteristically different lambing rates of domestic breeds of sheep are known to be reflections of similar variations in ovulation rates. In many breeds, increased lambing rates have been shown to follow gonadotrophininduced superovulation, thus indicating that the uterus has the potential capacity to support more offspring than natural ovulation rates permit. However, from studies of prenatal losses in superovulated ewes (Robinson, 1951) and after egg transfer (Moore \& Rowson, 1960; Moore, 1968), it is apparent that losses become increasingly severe as the number of eggs entering 
the uterus is increased. Robinson (1951) proposed that the level to which litter size was reduced, when ovulation rate was not limiting, represented the 'Maximum Potential Fertility' of the ewe. He suggested that this level was determined by both maternal and embryonic factors, and was probably characteristic for each breed of sheep.

The objects of the experiments reported here were: (i) to study the effect of maternal breed on the number of offspring which the uterus has the capacity to support and to determine whether this was related to the natural ovulation rates of the breeds concerned, and (ii) to show whether the breed of the embryos in the uterus influenced the number of them which were able to survive to term. To accomplish this, groups of five fertilized eggs of known genetic origin were transferred to the uteri of ewes of breeds known to be of low (Romney Marsh), medium (Suffolk) and high (Finnish Landrace) natural fertility and their resulting reproductive performance was recorded.

\section{MATERIALS AND METHODS}

The data presented were collected in five experiments. The influences of maternal factors in determining litter size were investigated by transferring fertilized eggs, at a rate of five per recipient, from 146 Clun Forest ewes to fifteen Romney Marsh ewes (Exp. 1), sixteen Suffolk ewes (Exp. 2) and fifteen Finnish Landrace ewes (Exp. 3). Since the number and the breed of the eggs transferred to each ewe was the same, any difference between the three breeds in reproductive performance should therefore have been the result of differences in the capacities of their uteri to support offspring.

In Exp. 4, fertilized eggs, again in groups of five, were transferred from a total of twenty-six Romney Marsh ewes to twelve Romney Marsh recipients, and in Exp. 5, eggs from ten Finnish Landrace ewes were transferred to eleven Romney Marsh recipients. Thus, the effect of the breed of the embryos on litter size could be compared in Romney Marsh ewes when they carried native Romney Marsh eggs (Exp. 4) or alien Clun Forest (Exp. 1) and Finnish Landrace (Exp. 5) eggs.

Details of the breeds of the recipient ewes and transferred eggs in Exps 1 to 5 are summarized in Table 1.

\section{Experimental procedures}

The oestrous cycles of the donor and recipient ewes were synchronized by the use of progestagen-impregnated vaginal sponges ('Synchromate', G. D. Searle and Co.; 'Vermix', Upjohn Ltd). All of the ewes were run together with raddled, vasectomized rams and examined twice daily for service marks. On Day 12 of oestrous cycles subsequent to the first synchronized heat after sponge withdrawal, groups of ewes which were to be used as donors were treated with PMSG. When they were observed in oestrus, donor ewes were removed from the flock and mated with fertile rams of the appropriate breed. Recipient ewes were selected from the flock if they were in oestrus within $24 \mathrm{hr}$ of the donor.

Between Days 3 and 5 after the onset of oestrus, eggs were recovered from 
donor ewes and transferred to the recipients using the methods described by Hunter, Adams \& Rowson (1955). The recovered eggs were examined microscopically $(\times 100)$; any unfertilized or abnormal eggs were discarded. Pending transfer to recipient ewes, the eggs were held in sterile sheep serum at $37^{\circ} \mathrm{C}$. The maximum duration of storage was $180 \mathrm{~min}$ and the average, $70 \mathrm{~min}$. So far as was possible, all five of the eggs transferred to each recipient were from a single donor, but in some cases eggs from more than one donor were mixed to make a group of five. At the time of transfer, the number and site of ovulations (corpora lutea) in the recipient ewes were recorded. Three of the eggs were then transferred into the uterine horn adjacent to the ovary containing corpora lutea if unilateral ovulation had occurred, and the remaining two eggs were placed in the opposite horn.

After recovery from surgery, the recipient ewes were kept with a raddled vasectomized ram through the remainder of the breeding season and examined daily for service marks. Ewes which remained pregnant were allowed to lamb and the numbers of lambs born, the sex and birth weight of each lamb were recorded.

\section{RESULTS}

The mean natural ovulation rates, recorded from counts of corpora lutea at the time of egg transfer, and the proportions of the recipient ewes which conceived and subsequently lambed in each of the five experiments are shown in Table 1. The ovulation rate of Finnish Landrace ewes was significantly greater $(P<0.05)$ than that of Suffolk ewes which was, in turn, greater $(P<0.05)$ than that of Romney Marsh ewes.

\section{TABLE 1}

THE MEAN OVULATION RATE (CORPORA LUTEA) OF REGIPIENT EWES, AND THE EFFEGT OF BREED OF REGIPIENT AND BREED OF EGGS ON THE PROPORTION OF EWES LAMBING

\begin{tabular}{|c|c|c|c|c|c|c|}
\hline \multirow[b]{2}{*}{ Exp. } & \multicolumn{2}{|c|}{ Breed } & \multirow{2}{*}{$\begin{array}{l}\text { No, of } \\
\text { ewes }\end{array}$} & \multirow{2}{*}{$\begin{array}{c}\text { Mean ovulation } \\
\text { rate }\end{array}$} & \multirow{2}{*}{\multicolumn{2}{|c|}{$\begin{array}{l}\text { Ewes lambing } \\
\text { No. (\%) }\end{array}$}} \\
\hline & Recipient & Eggs & & & & \\
\hline $\begin{array}{l}1 \\
2 \\
3 \\
4 \\
5\end{array}$ & $\begin{array}{l}\text { Romney Marsh } \\
\text { Suffolk } \\
\text { Finnish Landrace } \\
\text { Romney Marsh } \\
\text { Romney Marsh }\end{array}$ & $\begin{array}{l}\text { Clun Forest } \\
\text { Glun Forest } \\
\text { Clun Forest } \\
\text { Romney Marsh } \\
\text { Finnish Landrace }\end{array}$ & $\begin{array}{l}15 \\
16 \\
15 \\
12 \\
11\end{array}$ & $\begin{array}{l}1 \cdot 4 \\
2 \cdot 1 \\
2 \cdot 6 \\
1 \cdot 4 \\
1 \cdot 3\end{array}$ & $\begin{array}{c}13 \\
12 \\
14 \\
8 \\
8 *\end{array}$ & $\begin{array}{l}86 \cdot 7 \\
75 \cdot 0 \\
93 \cdot 3 \\
66 \cdot 7 \\
72 \cdot 7\end{array}$ \\
\hline
\end{tabular}

* One other ewe aborted five fetuses on Day 56 of gestation.

When Clun Forest eggs were transferred (Exps 1,2 and 3), the proportion of recipients which lambed was greatest in Finnish Landrace ewes and, whereas both of the Romney Marsh ewes and three of the four Suffolk ewes which failed to lamb returned to oestrus after normal dioestrous intervals, the only Finnish Landrace ewe which failed to lamb returned to oestrus on Day 59. The occurrence of late embryonic death and resorption was therefore indicated. 
Lambing rate tended to be poorer in Romney Marsh ewes when Romney Marsh eggs were transferred (Exp. 4) than when Clun Forest (Exp. 1) or Finnish Landrace (Exp. 5) eggs were transferred. The four ewes which failed to lamb in Exp. 4 returned to oestrus after intervals of 15, 15, 38 and 42 days. Two of the three ewes which failed to lamb in Exp. 5 returned to oestrus after 25 and 35 days; the third ewe aborted five fetuses on Day 56 . The variations in lambing rate in these five experiments were not statistically significant.

Table 2 shows the mean ovulation rate, distribution of litter size and mean litter size from the ewes which lambed in each experiment. When Clun Forest lambs were carried, Finnish Landrace ewes (Exp. 3) tended to have larger litters than Romney Marsh and Suffolk ewes (Exps 1 and 2), but this difference was not significant. When Romney Marsh ewes carried Clun Forest (Exp. 1), Romney Marsh (Exp. 4) or Finnish Landrace (Exp. 5) lambs, there was no significant difference in their performance, although quadruplets tended to be more frequent in the latter experiment.

\section{TABLE 2}

THE DISTRIBUTION OF LITTER SIZES AND MEAN LITTER SIZE AFTER TRANSFER OF FIVE EGGS RELATIVE TO THE MEAN NATURAL OVULATION RATE OF REGIPIENT EWES WHICH LAMBED IN EAGH EXPERIMENT

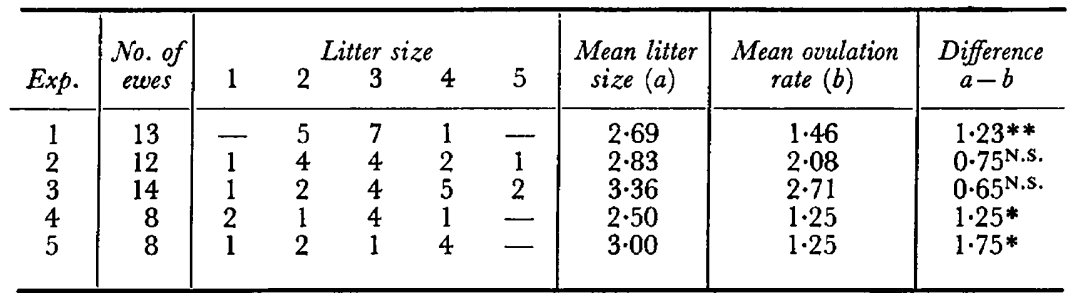

N.s. $P>0.05 ; * 0.05>P>0.01 ; * * P<0.01$.

In all five experiments, the mean litter size after transfer of five eggs exceeded the mean natural ovulation rate of the recipient ewes. This difference between potential reproductive performance, as measured by ovulation rate, and actual litter size after five eggs were transferred was statistically significant in Romney Marsh ewes and amounted to increases of 1.23, 1.25 and 1.75 lambs per ewe when Clun Forest (Exp. 1), Romney Marsh (Exp. 4) and Finnish Landrace (Exp. 5) eggs, respectively, were transferred. Since litter size was similarly increased in Romney Marsh ewes, both when they carried lambs of their own or an alien genotype, it is evident that ovulation rate normally limits the number of embryos in this breed to a level which is below that which the uterus has the potential capacity to support. In Suffolk and Finnish Landrace ewes, ovulation rate and uterine capacity appear to be more closely related.

The proportions of transferred eggs which survived to term in each experiment are shown in Table 3. These reflect the sum of the effects of the total losses of eggs in ewes which failed to lamb and the partial losses of some of the transferred eggs in ewes which remained pregnant. Significantly more $(P<0.05)$ Clun Forest eggs survived in Finnish Landrace ewes (Exp. 3) than in Romney Marsh or Suffolk (Exps 1 and 2) ewes. In Romney Marsh ewes, the proportion 
of eggs which survived tended to be poorer when native Romney Marsh eggs were transferred (Exp. 4) than when alien Clun Forest or Finnish Landrace (Exps 1 and 5) eggs were transferred. This effect was not significant. The loss of five fetuses by a ewe in Exp. 5 which aborted on Day 56 and the previously mentioned delayed returns to oestrus which occurred in some ewes suggest that these rates of survival may have been different in early gestation.

The ratio of male to female lambs born in these experiments was $51 \cdot 3: 48 \cdot 7$. Clearly, survival of neither sex was specifically affected by the conditions of experiments.

TABLE 3

THE EFFEGT OF BREED OF RECIPIENT AND BREED OF EGGS ON THE PROPORTION OF TRANSFERRED EGGS SURVIVING TO TERM IN EWES

\begin{tabular}{|c|c|c|c|c|c|}
\hline \multirow[b]{2}{*}{ Exp. } & \multicolumn{2}{|c|}{ Breed } & \multirow{2}{*}{$\begin{array}{l}\text { No. of eggs } \\
\text { transferred }\end{array}$} & \multirow{2}{*}{$\begin{array}{l}\text { No. of lambs } \\
\text { born }\end{array}$} & \multirow{2}{*}{$\begin{array}{l}\text { Percentage of } \\
\text { eggs surviving } \dagger\end{array}$} \\
\hline & Recipient & Eggs & & & \\
\hline $\begin{array}{l}1 \\
2 \\
3 \\
4 \\
5\end{array}$ & $\begin{array}{l}\text { Romney Marsh } \\
\text { Suffolk } \\
\text { Finnish Landrace } \\
\text { Romney Marsh } \\
\text { Romney Marsh }\end{array}$ & $\begin{array}{l}\text { Glun Forest } \\
\text { Glun Forest } \\
\text { Clun Forest } \\
\text { Romney Marsh } \\
\text { Finnish Landrace }\end{array}$ & $\begin{array}{l}75 \\
80 \\
75 \\
60 \\
55\end{array}$ & $\begin{array}{l}35 \\
34 \\
47 \\
20 \\
24 *\end{array}$ & $\begin{array}{l}46 \cdot 7 \\
42 \cdot 5 \\
62 \cdot 7 \\
33 \cdot 3 \\
43 \cdot 6\end{array}$ \\
\hline
\end{tabular}

* See Table 1 .

$\uparrow$ Significance in $\chi^{2}$ tests: 1 versus $2:$ N.S.; 1 and 2 versus $3: P<0.05 ; 4$ versus 1 and $5:$ N.S.

\section{DISCUSSION}

The natural ovulation rates of Romney Marsh and Suffolk ewes in the present series of experiments were comparable with those reported for these breeds by other workers (Averill, 1955; Moore \& Rowson, 1960; Quinlivan, Martin, Taylor \& Cairney, 1966). There appear to be no published data on ovulation rate in the Finnish Landrace breed. In Finland, Maijala (1966) found the mean litter size of this breed was 2.5 lambs per ewe and, in this country, mean litter sizes of 3.4 (Donald \& Read, 1967) and 2.9 (Land, 1970) have been reported. In view of these litter sizes, the ovulation rate of 2.6 in Finnish Landrace ewes in these experiments seems low.

The most important finding here was that, when the number of fertilized eggs entering the uterus was the same in all three breeds, the sizes of the litters born to Romney Marsh ewes were comparable with those of Suffolk and Finnish Landrace ewes. In achieving this, Romney Marsh ewes supported significantly more fetuses than would have been expected from consideration of their natural ovulation rates. Following transfer of five eggs, the litter size of Suffolk and Finnish Landrace ewes was not significantly increased over the potential size indicated by their natural ovulation rates. These results indicate that ovulation rate is a more important source of between-breed variations in fecundity than are the effects of differences which may exist in uterine capacity. Gordon (1958) drew a similar conclusion from observations of the response, in terms of lambing rate, of low and high fertility breeds and flocks to treatment with PMSG. $\mathrm{He}$ was, however, unable to observe ovulation rate and, therefore, could not show whether all groups had responded equally to his treatments. 
In the present experiments, the effects of maternal and embryo genotype on conception rate and litter size were not significant. There were, however, variations in both of these parameters and their total effect was apparent when the overall survival of transferred eggs was considered (Table 3 ). The significantly better survival of Clun Forest eggs in Finnish Landrace ewes than in Romney Marsh and Suffolk ewes indicates that ewes of the former breed, despite their smaller body size, have the capacity to support more offspring in utero than the latter breeds. A larger experiment is required, however, to demonstrate the separate effects of maternal breed on conception rate and litter size conclusively. Moore (1968) found that after transfer of three eggs, irrespective of the genotype of the eggs, large Border Leicester ewes had more triplet and fewer singleton pregnancies than smaller Merino ewes. The contrary result of the present experiments suggests that the factors which determine the number of embryos which will survive in the uterus are more specific than a simple relationship to body size.

In Romney Marsh ewes, the proportion of eggs which survived was not significantly affected by the genotype of the transferred eggs, though the survival of native Romney Marsh eggs tended to be poorer than that of alien Clun Forest or Finnish Landrace eggs. Clarke \& Kirby (1966) have suggested that immunological mechanisms affecting placental development could favour the survival of embryos which are antigenically dissimilar from the mother. Such an effect could have operated in the present experiments, but further experimentation is necessary to confirm this.

In practice, litters of more than two or at most three lambs are unlikely to be acceptable. Thus, although the upper limits of uterine capacity have not necessarily been demonstrated for the breeds studied in these experiments, it is clear that any limitation imposed by the uterus does not operate to reduce litter size below desirable levels in either the Romney Marsh or the more highly fertile Suffolk or Finnish Landrace breeds. Moreover, in these experiments, lambs born to Romney Marsh ewes were heavier than lambs of similar genotype born to Suffolk and Finnish Landrace ewes, and Romney Marsh lambs were heavier than Clun Forest and Finnish Landrace lambs when all three were carried by Romney Marsh ewes (unpublished data). Removal of the limitation on fecundity imposed by low ovulation rate in the Romney Marsh breed should, therefore, enable them to equal other more highly fertile breeds in reproductive performance.

\section{REFERENCES}

Averill, R. L. W. (1955) Fertility of the ewe. Stud. Fert. 7, 139.

CLARKE, B. \& KIRBY, D. R. S. (1966) Maintenance of histocompatibility polymorphisms. Nature, Lond. 211, 999.

Donald, H. P. \& ReAd, J. L. (1967) The performance of Finnish Landrace sheep in Britain. Anim. Prod. 9, 471.

GoRDon, I. (1958) The use of progesterone and serum gonadotrophin (PMS) in the control of fertility in the sheep. I. The hormonal augmentation of fertility in the ewe during the breeding season. 7. agric. Sci., Camb. 50, 124.

Hunter, G. L., Adams, C. E. \& Rowson, L. E. (1955) Interbreed ovum transfer in sheep. F. agric. Sci., Camb. 46, 143. 
LAND, R. B. (1970) A relationship between the duration of oestrus, ovulation rate and litter size of sheep. 7. Reprod. Fert. 23, 49.

Matjala, K. (1966) Causes of variation in litter size in Finn-sheep ewes. 9th Int. Congr. Anim. Prod., Edinburgh. Abstracts, p. 29.

Moore, N. W. (1968) The survival and development of fertilized eggs transferred between Border Leicester and Merino ewes. Aust. 7. agric. Res. 19, 295.

Moore, N. W. \& Rowson, L. E. A. (1960) Egg transfer in sheep. Factors affecting the survival and development of transferred eggs. 7. Reprod. Fert. 1, 332.

Quinlivan, T. D., Martin, C. A., TAYlor, W. B. \& Cairney, I. M. (1966) Estimates of pre- and perinatal mortality in the New Zealand Romney Marsh ewe. I. Pre- and perinatal mortality in those ewes which conceived to one service. 7. Reprod. Fert. 11, 379.

Rosinson, T. J. (1951) The control of fertility in sheep. Part II. The augmentation of fertility by gonadotrophin treatment of the ewe in the normal breeding season. F. agric. Sci., Camb. 41, 6. 